\title{
Russian Philanthrocapitalism
}

Elisabeth Schimpföss1

Lecturer in Sociology and Policy

Aston University

Aston Triangle, Birmingham, B4 7ET, United Kingdom 


\begin{abstract}
This article investigates philanthropic practices among Russia's super-rich. Based on interviews with multimillionaires and billionaires, it ponders whether and to what extent philanthrocapitalist concepts are compatible with traditional Russian approaches to elite philanthropy, which have been shaped and controlled by country's strong state. Overall, consciously and unconsciously, Russian philanthropists have selectively adopted a number of philanthrocapitalist principles, while some of them merge them with beliefs molded by their Soviet past and their self-perception as belonging to the intelligentsia. Based on diverse and eclectic models, they have constructed distinct ideas about their lives and their role in Russian society. This acts as a lever to build up trust in the new social hierarchy and fashion a new generation of supposedly deserving upper-class youth.
\end{abstract}

Keywords: billionaires, charity, philanthropy, Russia, elite, legitimacy 


\section{Russian Philanthrocapitalism}

\section{Introduction}

Delving into the world of Russia's super-rich, this article investigates the historical and cultural features of their philanthropic practices and asks to what extent they are compatible with the idea of philanthrocapitalism. Such a research agenda raises several issues: First, these mega-wealthy individuals are striving to justify their wealth in a society where, not so long ago, wealth was considered a crime and where today the gap between rich and poor has grown to become one of the widest in the world. Second, philanthrocapitalism is, by design, the antithesis to Russia's history of philanthropy, which has always existed within the control of a very strong state.

Third, the new wealthy elite in Russia lacks the birthright of a capitalist class that was brought up with bourgeois values and had instilled into them a sense of entitlement. This is highly problematic: as Weber reiterated, the holders of power and wealth want to believe that they deserve their good fortunes due to who they are and what they constitute (Weber 1991: 271). With the first generation of Russia's superrich having cemented their wealth, it has become more important to them to feel that they deserve the positions they occupy and the benefits they have accrued.

This was not an issue in the early post-Soviet period. The 1990s were dominated by the extreme prestige of money, no matter how it was acquired. Now that they have emancipated themselves from the urge to make more money, as Bourdieu described, the privilege of wealth (1984), there has been a shift towards more intellectual and spiritual needs and a desire to display more cultured traits and find some sense in life (Schimpfössl 2014). This is particularly important for the oldest upper-class members, who have began to think about the legacy they leave 
after their death. As a consequence of this change in priorities, social responsibility has become obligatory, and there has been a rapid rise in charitable giving in the new millennium.

To this end, I argue, the new philanthropists rely on the Soviet intelligentsia as a substitute for the lack of a bourgeois predecessor and recycle Soviet templates, that is, intelligentsia values filtered through the Soviet experience (Schimpfössl 2018: 97; 83). This does not prevent them from, simultaneously, adopting philanthrocapitalist ideas. It is often one and the same person that features several contradictory elements.

\section{Defining philanthrocapitalism and elite philanthropy}

Philanthrocapitalism postulates that the application of for-profit business methods in philanthropy is superior to traditional public-sector or civil-society approaches and has a substantially greater impact on social change. Its advocates devote a lot of attention to impact and to measuring impact, as well as leveraging other money, primarily from governments, to achieve this impact. The term stems from a book by Matthew Bishop and Michael Green, Philanthrocapitalism: How the Rich Can Save the World and Why We Should Let Them (2008), with a forward by Bill Clinton. The Clinton Foundation trades as a model example of philanthrocapitalism, as do the Bill \& Melinda Gates Foundation and the Chan Zuckerberg Initiative.

"Philanthrocapitalism" also applies to cases where (social) entrepreneurs and investors drive innovations or ventures that claim to produce long-term effects with wider social benefits. As such, social entrepreneurs, venture philanthropists, and social investors declare to pursue not only the narrow goal of increasing their own wealth, but go beyond by giving back to society and assuming leadership in global social change through philanthropy. 
In response to that, many scholars and commentators have fundamentally questioned the positive impact of this supposedly new and innovative approach to philanthropy.

First, they see nothing new about philanthrocapitalism, except for a stunning new level of openness towards admitting the benefits from procures through philanthropy (McGoey 2012:193). For over a century, philanthropists have sought to model philanthropic giving on corporate practices, McGoey argues (186-189): conflating the market economy's benefits for the common good was already part of Adam Smith's The Wealth of Nations.

Second, critics envisage highly detrimental effects of large-scale giving on democracy (McGoey 2015; Edwards 2010; and Callahan 2017). Wealthy benefactors use their private and corporate wealth to pursue their individual policy agenda. They might make choices that may affect millions of people, without, as individual actors, being able to oversee the consequences of these choices for societies at large. Tax reductions for philanthropy deprive state budgets of millions otherwise potentially used for social welfare and public infrastructure. This shifts the power further towards wealth elites: the super-rich set policy priorities, without being elected by anybody and without any accountability to anybody but themselves (even where taxpayers' money is used to match their donations).

In contrast to such a macro-perspective and political critique, sociologists of elites typically explore philanthropy from a perspective of elite legitimation and reproduction. One of the most seminal studies in this tradition is Why the Wealthy Give by Francie Ostrower (1995), who explored the elite culture of affluent donors in New York City. ${ }^{1}$ Ostrower paid particular attention to her wealthy respondents' class identity and how they use philanthropy to promote an elitist way of life. This take on 
elite philanthropy is central to this article because it outlines the specifics of philanthropy as a means to gain legitimacy, secure and control class boundaries, and perpetuate social positions across generations.

Philanthropy has been defined in many different ways, and there are long debates as to how it relates to charity. I draw on Ostrower's definition of philanthropy, which includes charity and patronage, as well as almsgiving and the encouragement of self-help (1995: 4, 20). In her understanding, charity is specifically directed towards the poor, whereas philanthropy has a broader concept. The latter does include charity, but it also encompasses the wider practices of private giving to the arts, environmental causes, health and rehabilitation, education, universities, museums, religious organizations, parks, cultural institutions, youth and urban development.

\section{Empirical data}

The material analyzed in this article is drawn from a set of 80 interviews with entrepreneurs, their spouses or children, which I conducted between 2008 and 2017, mostly in Moscow. Their characteristics are typical of the post-Soviet elite, the most salient of which is that they are highly educated (Kryshtanovskaia 2004: 341-342). For this article I selected twelve interviewees, eight with men and four with women. They all are philanthropists and run their own foundation or charity (many of them parallel to their corporate foundations) or were co-founders of a foundation and have ever since been heavily involved. The eight men are the breadwinners in their families. Three of the four women are the wives of wealthy Russian men; the fourth is a sibling. Except for one couple, whom I interviewed in 2009, these selected interviews took place between 2015 and 2017. 
The two earlier interviews, which took place in 2009, were with Maria Eliseeva and Ilia Segalovich, the cofounder of Yandex, the world's fourth largest search engine and Russia's equivalent to Google. Segalovich died from cancer in 2013, not having reached the age of fifty. His wife, Eliseeva set up her charity Deti Marii (Maria's Children) in the early 1990s and both were active in running its activities.

Veronika Zonabend is married to Ruben Vardanian, born 1968, formerly CEO and controlling shareholder of Troika Dialog, an investment bank. His assets were worth $\$ 950$ million in $2017 .^{2}$ Through their foundation, Initiatives for Development of Armenia, they run an international boarding school, United World College Dilijan in Armenia, which Veronika looks after. Her husband is heavily involved in the development of Skolkovo Moscow School of Management, which he co-founded and where a research center was created in 2013 for the study of philanthropy, social entrepreneurship, and ways to pass down assets from the first generation of wealthy people in Russia to the next.

Irina Sedykh is the wife of the metallurgy tycoon Anatolii Sedykh, the main shareholder of United Metallurgical Company (OMK), Russia's second-largest pipe producer and biggest maker of train wheels. He is also the President of the OMKUchastie (OMK-Participation) Charity Fund, which focuses on education, health, and children with special needs. Irina Sedykh chairs the Fund's supervisory board and is heavily involved in its activities.

The fourth woman is Irina Prokhorova, born 1956, the sister of Mikhail Prokhorov, born 1965, who led Russia's rich list in 2009 with assets of $\$ 22.6$ billion (down to $\$ 8.9$ billion in 2017). Prokhorova is the founder of New Literary Observer, the main intellectual journal and publishing house in Russia. She leads a philanthropic 
foundation which is named after her brother.

Piotr Aven, born 1955, is Chairman of Russia's biggest private bank, AlfaBank. In 2016 his assets were worth $\$ 4.6$ billion. He is co-founder of Liniia Zhizni (Life Line), a charity that organizes surgeries for children, and of Genesis Philanthropy Group, which supports Russian-speaking Jews worldwide. Aven regularly lends pieces of his art collections to museums. He sits on the board of trustees for a range of museums, universities, and other institutions.

Vadim Moshkovich, born 1967, is the head of the agro-industrial holding company Rusagro, Russia's largest sugar and pork producer. In 2016, his assets amounted to $\$ 2.3$ billion. His main philanthropic activity is the development of a flagship school for highly gifted children. $\$ 50$ million of his private money has gone into the project and $\$ 150$ million into an endowment fund that will help keep things running.

Alexander Svetakov, born 1963, also specializes in schools, however, in contrast to Moshkovich, schools for disabled children. Svetakov is the owner of Absolut Group, which has interests in real estate, trading, and insurance. His assets amount to $\$ 3.3$ billion in 2017 .

Roman Avdeev, born 1967, owns Moscow Credit Bank, one of Russia’s biggest in terms of assets. His wealth in 2014 was assessed at $\$ 1.4$ billion. He runs a foundation working with orphans and foster parents.

Ziyavudin Magomedov, also born in 1967, is the main owner of Summa Group, which invests in port logistics, engineering, construction, telecommunications, and oil and gas. His wealth amounted to $\$ 1.4$ billion in 2014. His PERI Charitable Foundation largely works in Dagestan, his country of birth; however, their financing might dry up soon. Magomedov was about to fly to the United States with his family 
in late March 2018 when he and his brother were arrested and charged with setting up an organized crime group and embezzlement of state funds. On May 30 the court extended the arrest until August 5. In the very worst case, Magomedov could get a prison sentence of thirty years (Starinskaia 2018).

The remaining two interviewees are not billionaires. How rich they are is difficult to tell. Igor Tsukanov, born 1962, is a former financier and the only one who permanently lives in London. When asked in interviews, he never gives a price tag to his wealth. His collection of post-war Russian art is one of the biggest in the world. He organizes his various philanthropic projects through the Tsukanov Family Foundation. Oleg Sysuev, born 1953, is an Alfa-Bank board member. In the 1990s, he was deputy head of the presidential administration, the government's vice prime minister, and minister of labor. Sysuev is a founding member of Liniia Zhizni, together with Piotr Aven and others.

\section{Philanthrocapitalist ideas among Russia's super-rich}

The current generation of super-rich grew up on Soviet propaganda, which taught them that the capitalist system inevitably spawns gains for a few to the detriment of the masses. Reality in the 1990s very much confirmed this Soviet propaganda take on capitalism: while the new wealth elites enriched themselves speedily, the country's GDP shrank by a half and the population's living standards crumbled and poverty exploded (Scheidel 2017: 222).

During the long oil boom of the 2000s the memory of Soviet propaganda and the 1990s cut-throat capitalism faded, thus giving way to philanthrocapitalist ideas. The oligarch Aven believes that the private sector will be supplanting the state and that private money will increasingly finance social infrastructure, covering everything 
from medicine to culture. He sees this as inherent in the logic of the market, stating: "Where capitalism develops, private philanthropy will emerge and grow." Aven considers a strengthening of philanthropy to be of particular importance to Russia: it will help rehabilitate private property.

Liniia Zhizni, set up by the shareholders of Aven's bank, was the brain child of the oligarch Mikhail Fridman. Sysuev, one of the shareholders, told me: "Misha [Mikhail] used his success in business and applied it to charity: business technology, good management, motivated with clear tasks, audit, and control.” Sysuev pondered the weaknesses of this approach: "What we don't have enough of are those emotional drivers, enticed by the soul," he admitted. "But maybe that's also good. We don't give money if we can't control it to the end."

According to the former financier Igor Tsukanov, successful businesspeople know best how to achieve a particular result, how to do a project, and how to organize a big event. They can easily switch from one project to another, and they can apply their skills to any field, not just in business. After he stopped doing business, he wanted to do something new: "But the new thing had to have parameters: clear objectives, a time frame, and a budget. These are the skills I acquired in business and applied to art." Tsukanov regards his own philanthropy as highly structured and is very happy with what he is doing; he is now one of the world's leading collectors of post-war Russian art: "Exhibitions require efforts, logistics, and intellectual input. They are large projects."

Other interviewees did not articulate philanthrocapitalist ideas that explicitly, but there were elements of it. In his project, Moshkovich wants "to have the goals clearly defined and to understand how to get there, how to measure success, etc." He is concerned about producing graduates whose skill set can compete with the West. 
Magomedov's Foundation runs an innovation business incubator to develop entrepreneurial IT technology skills among young people in Dagestan. Zonabend relates to philanthropy like to a market. She calls herself and her husband Vardanian social entrepreneurs. They were among the first who started "helping systematically. ... You need a system, otherwise there is no impact, and this system needs to be sustainable in the long run."

Philanthrocapitalism epitomizes freedom of choice, individualism, diversity, and the idea of promoting citizenly participation. The desire to express individualism and to experience this freedom of choice has a paradoxical result in Russia: People barely differ in their approaches. The vast majority of charity donors support children and giving aid to children is the major form of charity in Russia (Khodorova 2014; Skolkovo 2015: 78, 81).

This is, firstly, because only children are considered trustworthy in a society that is largely based on distrust (Hosking 2014). Secondly, support for children is an investment in the future of Russia, an issue the new upper class has become increasingly concerned about. Thirdly, support for children follows the Russian tradition of charity that emphasizes benevolence toward passive alms takers (Dinello 1998).

Philanthrocapitalism promotes the idea that competitive principles should be applied to the third sector. Edwards (2008) cautions that such principles might retard progress by pushing non-profits to economize in key areas of their work, eschew the most complicated and expensive issues, and avoid those most difficult to reach. In a pure form, competitive principles inevitably exclude care for groups with little "use" for society. This is, however, not the main reason why Russian philanthropists are little concerned about other groups than children, such as migrants, homeless people, 
drug addicts, ex-prisoners, or the long-term unemployed. Here near-social Darwinist attitudes, which were very prevalent in the dog-eat-dog world of the 1990s, prevail: Those who can work should do so and earn their own living, and those who are considered to have caused their own misery are not deserving of mercy (Schimpfössl 2018: 110).

\section{The state and philanthropy in Russian history}

Nascent philanthrocapitalist ideas are confronted by an ever more intrusive Russian state. In this respect, historically in Russia, there is very little ground for philanthrocapitalists to build upon. Philanthropy was initially confined to the aristocracy and the monarchy. The tsars kept tight control over who was allowed to give and to whom. At the same time they were showing largess themselves, as well as permitting the ladies of the court to keep themselves occupied with philanthropic giving. The result were a great number of educational and healthcare institutions as well as institutions of art and culture (Khodorova 2014). An example of this is the State Hermitage, based on the collection of Catherine the Great, which opened to the public in 1852.

By the mid- to late-nineteenth century, when Russia's industrialization took on pace, industrialists, financiers, and merchants accumulated sufficient wealth to divert some of it to charitable causes. This philanthropy covered a wide range of areas, from cultural institutions and the arts to social trusteeships or social welfare (Dinello 1998: 117-9).

This period is most strongly imprinted in today's philanthropists' minds.

Zonabend told me that in 1913 fifty percent of all educational institutions were funded by private philanthropists, and Christian schools were all privately funded, by money 
from the community, the church, and private individuals: "The rich felt a duty to support the development of their country," she evaluated their giving very positively, relating it back to the character of the state:

It has always been like this here. We have always had a heavy bureaucracy with people at the top who have never particularly cared about the wellbeing of their people. So the responsibility to care about the country and its people has fallen to the rich.

Moving on to the 1917 Revolution, Zonabend deplored that this feeling of duty was lost. Even worse, "many philanthropists of that time cut the bench they were sitting on and supported the revolutionaries."

Under Soviet rule, the authorities fully institutionalized social welfare and forbade all philanthropic activities. They perceived them as a capitalist practice that undermined the role of the Communist Party (Kurilla 2002). Philanthropy lived on, however operating under different terms. High-ranking party members patronized the arts even in toughest of all times, the 1930s (Fitzpatrick 2015). In the post-war Soviet Union, charity was routinely provided through the various communist party organizations (Dinello 1998: 115). Some of my interviewees, such as Segalovich, remembered those disguised charity activities very clearly, as well as their own commitment to them when visiting orphanages and the like.

The early benefactors in the 1990s fancied themselves as following in the footsteps of pre-revolutionary role models, such as art patrons like Tretiakov and Morozov and impresarios like Diaghilev. Many of their activities were, however, oneoff actions; sporadic, unfocused, and uncoordinated. The population dismissed most of them as PR stunts as well as attempts to merely sooth a guilty conscience and schmooze with the authorities (Gambrell 2004). 
After the economy had recovered from the 1998 financial crisis, charity rose rapidly (Khodorova 2014). An increasing number of businesses began institutionalizing their corporate philanthropy programs through corporate foundations. Major shareholders sometimes played a key role in this. Russian companies also began to embrace the notion of corporate social responsibility (Coutts 2014).

This was influenced in part by intensified encounters with their Western counterparts and in part by Putin. Frequently using the term "social responsibility," Putin made it clear from early in his presidency that he expected those who accrued a certain level of wealth to help fill the vacuum left by the withdrawal of the state. His encouragements had their intended effect. In 2006 almost 90 percent of donations in Russia went to state-run bodies such as local orphanages and cultural institutions, financing health care, nursery homes, orphanages, and cultural institutions, and thereby stepping in where the state had failed (Livshin and Weitz 2006).

Cynics in Russia claim that such philanthropic efforts (often called "social tax") are the necessary pay-offs to remain in Putin's good books. Roman Abramovich was famously obliged to pump large sums into Chukotka, a remote region in the Far East he had no previous link to but which he represented for years in the Federation Council, the Russian upper house. Some equally doubt that Magomedov's interest in his parental country Dagestan was primarily driven by care and compassion, rather than being a "necessary evil for winning favor with the Kremlin" which is keen to see Islamic extremism in the region contained (Dzutsati 2014).

In 1999, Vladimir Potanin, the wealthiest Russian in 2015, created the first private foundation, called after him. Since then, the number of private foundations has grown steadily. As of 2013, there were around seventy of them in Russia (Coutts 
2014). Many philanthropists have endowed their foundations. These private foundations have been established parallel to corporate foundations, and some philanthropists channel their personal philanthropy through their business.

It is not uncommon for foundations to implement projects directly, as opposed to using intermediary organizations. In other words, rather than allocating grants to specialized NGOs, the rich themselves renovate hospitals, develop health care services, publish books, and build schools. This approach has several reasons: First, many donors want to have full control over their activities. Second, formal organizations are perceived as impersonal. Third, the NGO sector in Russia is underdeveloped and seen as corrupt and fraudulent (Livshin and Weitz 2006; Khodorova 2014: 19; and Skolkovo 2015: 78, 81, 83).

Already suffering from its bad reputation and own inability, the nongovernmental sector suffered a big blow after the 2004 Orange Revolution. Putin accused foreign NGOs (among them, for example, Amnesty International) of being instruments of foreign influence, secretly undermining Russia's interests. The introduction of two laws specifically targeting NGOs - the "foreign agent" law in July 2012 and the "undesirable organizations" law in May 2015 - weakened the sector further.

While attacking the NGO sector, the government introduced a more favorable environment for private philanthropists (Coutts 2014). In 2007, the Endowment Law was passed, making the income earned from endowments tax free. In 2012, tax incentives were introduced for individual donors. The institutional setting has been adapting, and Kremlin-loyal NGOs have gained in strength and prestige (Robertson 2009). 
In many Western countries, philanthropists tend to give globally as well as in the area they are economically active, or in the neighborhood where they grew up (Freeland 2013: 73-74; Lloyd 2004: 55). Patriotism is an important feature of their giving, and Russian philanthropists almost exclusively focus on Russia. Within the country, however, there are a number of geographic peculiarities. As Russia's superrich are keen to control their giving and most of them live in Moscow, donations and philanthropic activities are concentrated in the capital and its surroundings (Coutts 2014).

Parallel to this, natural resources are sourced from often very remote areas and a lot of Russia's heavy industry is either energy-based or otherwise regionally concentrated. Most of these industrial centers were developed either in late Imperial Russia or in Soviet times. In both periods, the state played the most crucial role in industrializing the country (Blackwell 1974). When after the privatizations of the 1990s the oligarchs-to-be took over large industries left by the Soviet state, they often ended up as the main employers in the region or town where their production, mines, or oilrigs were located. A crumbling social infrastructure, aggravated by low wages and mass layoffs, caused severe social grievances. Whilst this did not officially fall under the remit of the new owners responsibilities, the highly desolate conditions in many regions nevertheless threatened to tarnish their image. In response, many corporations set up their foundations in the areas where their factories are located and stepped in to the vacuum created by the severely underfunded public infrastructure.

Some of the foundations set up by my interviewees are active regionally around their main businesses. Mikhail Prokhorov Foundation, led by his sister Irina Prokhorova, focus their work around the Siberian city Krasnoyarsk, where the 
oligarchs business is located. Theatre productions and cultural activities feature prominently in the Foundation's program. Moshkovich has built schools in Belgorod and other areas, around his businesses. Anatolii Sedykh has his main production in Vyksa, a town in the Nizhny Novgorod region. His foundation, led by his wife Irina, aims at "unifying the company's work also on a social level." She also organizes an annual cultural festival in the town.

Prokhorova's and Sekykh's commitment to cultural development is somewhat reminiscent of the mission Russian intellectuals - many of them from aristocratic backgrounds - pursued in the second half of the nineteenth century when they tried to teach the peasantry how to achieve a better life - some with a degree of paternalism, others with an enlightenment mission (Schimpfössl 2018: 106). "We want to unite people and encourage them to take part in other people's life," Sedykh said. She sees this as "a way of helping develop civil society." Practically, this works via "volunteer participation" in the provision of care for disabled children. It has taken off, she said; every year there are more volunteers than the charity can reasonably integrate into its work.

In theory, strong state dominance, which heavily interferes in individual and corporate philanthropy, is incompatible with the concept of philanthrocapitalism. However, the narrow, underdeveloped, and unregulated nature of the third sector in Russia reverses this logic. Those who know how to handle the Russian authorities enjoy great freedom. 'Sure, many things are not quite clear here. That's something one needs to simply accept," Zonabend said. "But the state is not interfering," she insisted. "In sum, there are great chances here. We have much fewer restrictions than you have in Europe." 


\section{Educating and enlightening the Russian people}

Fortunately for their protégés, the prospect of return of investment has never crossed some of my interviewees' minds. Eliseeva wants to enable the children she works with to develop themselves and learn to stand on their own feet. They are of disadvantaged backgrounds, many with severe learning difficulties, some mentally disabled. She and her team try to make them enjoy learning, and encourage them to stay in school and get a school diploma. Her husband told me that many people think that these children will never be able to read or write, but they proved them wrong: "Some of them even make it into college." Eliseeva explained their approach: "We paint together, we have music classes, theatre classes, clown classes, and so on." For the older ones, they offer evening classes; Spanish, Italian, English, literature, math. "You need to deal with these children and challenge them; then everything will be very different."

Market competition is neither a topic for Avdeev in his philanthropic activities. His life has been all about orphans, starting with the nineteen adopted children he has raised (out of twenty-three). He sees the key to improving the lives of orphans not with the state ("The state does a lot for orphans anyway."), but in winning the hearts of people able and potentially willing to foster children. He also tried (unsuccessfully) to work with parents who have given away their children; he wanted to provide them with psychological support.

Market-oriented thinking would not allow for Svetakov's school either. He set up a school for children with mental impediments. There is no great appetite for disabled children, he explained to me: "Our society likes the strong and healthy. It doesn't like the weak and ill." Many of the children in his school are physically disabled or the children of alcoholics. "It's not something many are comfortable with, 
you know," he said. Friends in politics and business tried to talk him out of his project: Why not a school for gifted children, they asked.

A school for gifted children is what Moshkovich set up. Within a new development project, he was contractually obliged to build fifty schools. As he sees schools as being crucial to "shape human beings (and all humans are able to be good"), he decided that, as he has to build schools, he would build only good schools: “A strong school is easily explained: It's an institution which develops a child not only in professional knowledge, competences, skills, morals, but has them undergo a complex development with clearly-set goals."

Moshkovich, who went to an elite school specializing in mathematics, is convinced that he owes his success in good part to his school education. (This one reason why he describes himself as "Soviet. I'm a product of the Soviet period.") Tsukanov went to the same school. He is also convinced that his education was excellent: "I don't know why the communists did that, but they did." Also in broader terms, he acknowledged the educational spirit in the Soviet Union, especially among educated families. "We had a big library at home and I grew up on books. It's a typical Soviet story. We had nothing else except education and books."

Most of my interviewees were born into the Soviet intelligentsia, which consisted of professionals engaged in the cultural and educational sector as well as academically trained medics, technicians, and engineers. By the time of Stalin's purges, the Soviet intelligentsia had largely lost their predecessors ideals of a humanistic search for truth and a self-effacing devotion to serving the people (Hamburg 2010). They retained, however, a strong patriotic feeling of duty to the state and the development of the country, as well as the nineteenth-century perception of society as being divided into two classes: the educated intelligentsia and the simple 
masses (Berlin 2008: 130-154). The former repeatedly went out to help the latter become empowered, seemingly selflessly, as did for example the Narodniks in the 1870s. In the following century, the Soviet intelligentsia wanted to think of themselves as enjoying freedom and independence of (vulgar) material urges (Schimpfössl 2018: 146).

Today, many upper-class Russians today embrace the intelligentsia as a group on whom to model themselves (Schimpfössl 2018: 97). This has been one of the drivers for the new economic elite to drop the ostentatious lifestyles they indulged in and identify with cultural symbols (Schimpfössl 2014). This somewhat reverberates in the interviewees' self-perceptions as well as in their attempts to enlighten the people. Some of my interviewees fancy themselves as moral leaders.

Paradoxically, this self-perception fits into philanthrocapitalist designs. Sysuev sees his duty in enlightening and educating common Russian people so to create "the social institute of charity" in Russia. Ordinary people should acquire a desire to do charity like "an everyday thing." The shareholders finance the charity's infrastructure and staff costs. The staff's main task is to fundraise among common people for the surgery and treatment of severely ill children. In this way, the shareholders believe, they can instill in the people a desire to make charity part of their lives; thus they will become part of civil society. Their end goal is, however, more ambitious: to "rehabilitate private property in Russia." Sysuev explained: "The relationship to rich people is complex here in Russia. There is still the widespread belief that big money is stolen." This was also the reason why, for many years, the shareholders kept their involvement secret. They feared that it could jeopardize the whole project. 
Magomedov, who strongly identifies with his parents' intelligentsia status, referred to a somewhat unusual role model: Peter the Great (1672-1725). Magomedov admires the Tsar for his radical modernizing project, including bringing European education to Russia. (Magomedov did remark on the ambiguity of a historical figure such as Peter the Great, having achieved a lot, but also having killed many people.) His Dagestan programs include two schools, two orphanages, and several nurseries. Although the country in the North Caucasus has gone through great difficulties, Magomedov still saw solid grounds for his programs to work. This is thanks to the Soviet legacy of investing generously in education, he explained.

\section{Social reproduction}

In one respect philanthrocapitalism cannot claim to make any difference when compared to previous philanthropic endeavors: its effect on legitimizing and recreating social class. Advocates of philanthrocapitalism evaluate this, however, positively; great riches generate extra money to be invested into social projects. Furthermore, social status obliges and nurtures a feeling of duty - noblesse oblige, as Georg Simmel reiterated ([1908] 1992: 820).

Individuals usually regard their giving and volunteering as personally motivated. However, philanthropic behavior is often not only formally regulated by the state, but also informally. The elite is sensitive to questions such as who gives to whom, who is allowed to give and who is allowed to receive. In the West, elite philanthropy is very much related to being accepted by and identified with longestablished, highly prestigious non-profit organizations. Becoming a trustee of one of those indicates that one has socially "arrived" (Ostrower: 1995: 36). In Russia, the same runs via informal practices based on personal relations of trust. Both play the 
role of social catalyst and controller of the boundaries of social class, deciding who belongs to which elitist circles (Schimpföss1 2018: 102-105). In addition to that, in line with Marcel Mauss ([1898] 2002), the exchange of donations that occur among donors creates a special sense of social obligation and interdependence.

Philanthropy is one of the most important tools to create a lasting legacy for the first generation of wealth, whose members are growing older and coming closer to death. The assets they have to pass on to their offspring are on an epic scale. We will soon see the biggest transfer of wealth the world has ever seen, if one considers the small number of people involved. Against this background, a certain training in philanthropy has become part of what is considered as proper upbringing.

Tsukanov is very happy with his children, especially once his son started showing an interest in his father's art collection and brought friends to his exhibitions. His daughter was interested anyway. This curiosity is partly due to Tsukanov's wife, he said: "My wife is responsible for our family's cultural calendar. Yesterday she took us to see Rakhmaninov at the Royal Opera House." For Tsukanov it is vital that his children know that there is "more than just their profession."

Avdeev's children are also very interested in the foundation and they discuss things very actively, but he said he tries not to pressurize them or drag them in too much. Like many others, he would be very happy if they continued running the foundation, but, like many others, he stressed that this should be their desire. "It's much more important to me that they live their own lives," he said. "The older they get, the less I try to give them advice. An older child has a right to make its own decisions and make their own mistakes." Avdeev's children will have plenty of chance to do so: they will not receive anything from their father beyond a high-quality education, accommodation, and a car. 
Zonabend and her husband, who will not pass on their wealth to their children either, discuss their philanthropic activities a lot with their children: "It's how we live, so it's a permanent topic. The school and everything is permanent topic of conversation. The younger children want to study at Dilijan, she said.

The children are proud if other people praise us to them, it's got special impact. That's very pleasant; we don't want to impose anything on them. It's very pleasant for me if they want to go to Dilijan. And it's not the most obvious choice to give up London and go to Armenia. If they want to go there themselves, it's probably a sign that we've done some things right.

This pride and identification within the family is likely to enable the children to find a place in society that will make them appear deserved in their own right, regardless of the fact that they were born into privilege.

\section{Social inequality}

Philanthrocapitalism is a phenomenon of our time, when social inequality is increasing and the wealth of a tiny group of super-rich has gone stratospheric. Never before in history has social inequality widened as rapidly as it has in Russia since the collapse of the Soviet Union (Scheidel 2017: 222; Therborn: 2013: 8). In 2013 Credit Suisse declared Russia as one of the countries with the highest level of wealth inequality in the world (Keating et al. 2013: 53). The plunge in oil prices in 2014 destroyed much of the gain made in the early 2000s in the living standards of ordinary Russians (Pirani 2010: 10; Tikhonova and Mareeva 2016: 162). However, rich Russians have hardly felt the consequences of neither the 2008 nor the 2014 crisis; the number of dollar billionaires recovered quickly (Forbes Russia 2017). 
Svetakov sometimes has difficulties understanding this fellow Russians: "Our people are particular. They've had everything taken away, but they still endure it." According to Aven, that should not cause him sleepless nights. Aven does not see any risk "whatsoever" of social protests erupting in Russia because "the population has become a lot richer in the last twenty, thirty years." He admitted that there is a problem of social inequality (which, shockingly to him, is already as high as in the United States, he added), but "the group of very rich people is very small and they live separately from the rest." As for tackling the problem of inequality, he sees the responsibility lying with the state: "It's a question of social policy. Social mobility must work. There mustn't be any nepotism."

Aven cautiously admitted to something raised by critics of philanthrocapitalism (Edwards 2008): in comparison to philanthropy, governments achieved far more over the last century through implementing social programs, especially when pressurized by social movements and civil society. The latter is something Avdeev remarked on. He seconds Aven in his view that it is not for the rich to be concerned with the challenges produced by social inequality ("rich people can contribute to the discussion"). Instead, "the discussion needs to run in civil society. The state depends on the opinion of its people." With this point, however, any common language with Aven ends. Very much in contrast to the economic liberal Aven, Avdeev's personal philosophy is guided by Soviet values, even Marxist ideas. He lamented that one crucial demand put forward by Karl Marx has not been implemented: the abolition of inheritance.

Aven and Avdeev are bankers, which might be one reason why they think on a macro-level. Industrialists seem closer involved in day-to-day business and their consequences, and this causes moral dilemmas. Anatolii Sedykh reduced his staff 
after the 2014 crisis hit. His wife told me that even up to the eleventh hour they tried to save their business projects, whether profitable or not. Their foundation has tried to mitigate the consequences of these layoffs, she assured me. Moshkovich seemed at conflict with the basic demands of capitalism and his own role in it: "I'm not a politician, I'm a small person. I don't deal with inequality. I don't care about inequality," he said. Social inequality, however, does bother him "in an empirical sense, in cases where I encounter it." His company employs 15,000 people. "When we increase productivity, this means mass redundancies. ... We need to sack people all the time." Even though he is not personally involved in any such executive processes, they clearly make him feel uneasy; after all, they clash with his idea of being responsible towards his workers, and his desire to secure them a decent life. ("We build houses for our employees, raise their wages, educate their children, and so on.")

Given the renewed social hardship large segments of the Russian population face, perhaps it makes sense that uneasiness spreads quickly among the super-rich. In some cases this goes further than contemplating to what extent there is a risk of uprising. "The April theses? Bread to all?" Avdeev asked me. "How could one possibly not agree with that?" He then told me that he appreciates Lenin, not least for his qualities as a gifted propagandist and journalist. As did Lenin, Avdeev also embraces progress. Russia has seen so much more of it in the last ten years than Europe has, he said and added that society also must change radically in relation to ecology. However, he cautioned to fall into any conspiratorial ideas: "Cataclysm is a fashionable topic, but I don't think that's very rational." 
He might see Zonabend being dangerously close to such ideas. Zonabend expects great challenges in the next ten years, potentially a global crisis of values and nature:

Will humanity survive? Will we be able to feed that many people? If we don't manage to shift our energy and food production, we'll run out of resources. If we don't go back to more natural lifestyles, we are done. Conflicts, epidemics, cataclysm, they all serve to reduce the world population. We are on the brink of massive changes. A tectonic shift from industrial to postindustrial society, a process which has long started.

She left me with a piece of life advice: "Live like you'd die tomorrow and study as if you'd live forever."

\section{Conclusion}

Philanthropy plays a great role in unifying the new upper class and legitimizing it across generations. The desire among super-rich to legitimize themselves increases the competition among them and their circles. Yet it also helps unite the privileged classes, strengthen ties between them, and facilitates cohesion among the various elite groups. Zonabend and Vardanian are in many respects spearheading Russia's new upper class. Her horizon is the planet's future, with her as a player in it, small, but not impotent. Their disinherited children received a great head start to build up seemingly meritocratic identities. He demonstrates a highly developed class consciousness by not only bothering about elite reproduction within his family, but on a class scale, having set up a center that deals specifically with how to pass down wealth from the first generation of wealth to the next. 
The same is true for Aven and Sysuev. McGoey grants philanthrocapitalism a genuine novel aspect: that the level of openness to admit private gain through giving is higher than ever before (2016: 194). The return on Aven's and Sysuev's investment into their charity - with the long-term aim to rehabilitate private property in Russia seems to be as bluntly as it gets to their own interest. Yet again, as with Vardanian, they pursue not their personal self-interest, but the interest of their class as a whole. It is with some irony that the shareholders hid their involvement for many years in fear of negative repercussions, exactly because public opinion regards their wealth as highly illegitimate (Levada-Center 2014).

A factor that has greatly facilitated their self-legitimization is their intelligentsia identity, and this echoes in their philanthropic practices. Although to different extent, Zonabend, Vardanian, Aven, and Sysuev are all on a mission to teach common fellow citizens civil society values. They presented themselves to me as educators and promoters of civil society. Moral leadership requires historicallyfounded status: birthright and entitlement - and that is what they have to work hard to claim for themselves by emphasizing their intelligentsia background.

There is, of course, a moment that dampens the beauty of these heroic efforts to assume moral leadership: the radical economic transformation in the 1990s, which brought about the precondition for my interviewees' riches, could become that radical only because civil society was far too weak to fight it. This was something which, back then, was warmly welcomed by not only the liberal reformers in Russia, but also their Western advisors, many of whom deplore the lack of a civil society in Russia today (Domrin 2003: 31f; Uhlin: 2013: 163). None of my interviewees delved into this, which is indicative for the fact that Russia's new upper class has not yet found an entirely convincing narrative for their money making. 
All this does not necessarily make them unsuitable for philanthrocapitalism if understood not as an ideological idea, but as a practical tool to justify wealth inequality, claiming that private and corporate surplus money sets free resources for philanthropy. Arguing in this vein is, however, highly complicated and contradictory: On the one hand, Svetakov and Eliseeva would not be able to run their projects for mentally disabled or otherwise disadvantaged children were it not for their riches. On the other hand, their projects would not exist if they reasoned in philanthrocapitalist terms. What they do does not fit into categories such as impact-oriented, measurable, result-based, market-savvy, high-performing, cost-effective, or financially profitable. Here philanthrocapitalist logic (some have to be rich so that they can do good) holds true while, simultaneously, collapsing.

In many other respects, Russia's first post-Soviet generation of wealth is historically unique: My interviewees were all born in the Soviet Union, most of them in the Brezhnev era. Their upbringing and education was Soviet and forms a major part of their identity. Refuting all this would mean denying, to some extent, their own worthiness. This creates some conflicting ideas in terms of what they want for society in relation to their role in the system and the new social hierarchy. This conflict is particularly apparent in Moshkovich, who perceives himself as a product of Soviet society, and Avdeev, who identifies with the ideological concepts that founded the Soviet project.

As specifically Russian, and little related to philanthrocapitalism, as such an analysis might sound, in a lighter and dampened version it has global parallels: The world's richest are increasingly borrowing some terminology traditionally ascribed to the socially caring, occasionally even radical, left when talking about their efforts to change the world with their movement and to connect with the common people 
(Forbes 2012). That such efforts naturally stop short of challenging the status quo with regards to wealth distribution explains why there is little tension between philanthrocapitalists and the state. This is true even for Russia. Sure, some of the rich resent having projects allocated to them by the authorities. However, once they submit to the game and play it right, Russia is full of opportunities for those well established within the power system. Merging philanthrocapitalist and Soviet ideologies, is in many ways doing the trick - and, to a large extent, characterizes Russia's new upper class and the philanthropists among it. 


\section{Acknowledgements}

I am grateful to The Leverhulme Trust for enabling this research through the award of a Leverhulme Early Career Fellowship.

\section{Biography}

Elisabeth Schimpfössl is author of Rich Russians: From Oligarchs to Bourgeoisie (2018). She has also conducted research into media and journalism. Schimpfössl is currently Lecturer in Sociology and Policy at Aston University.

\section{References}

Berlin, Isaiah. 2008. "The Remarkable Decade," Russian Thinkers, 130-154, edited by Henry Hardy and Aileen Kelly. London: Penguin, 2008.

Bishop, Matthew, and Michael Green. 2008. Philanthrocapitalism: How the Rich Can Save the World and Why We Should Let Them. London: A. \& C. Black.

Blackwell, W. L. 1974. Russian Economic Development from Peter the Great to Stalin. New York: Watts.

Bourdieu, Pierre. 1984. Distinction: A Social Critique of the Judgment of Taste. London: Routledge \& Paul Kegan. 
Breeze, Beth, and Theresa Lloyd. 2013. Richer Lives: Why Rich People Give.

London: Directory of Social Change.

Callahan, David. 2017. The Givers. Wealth, Power, and Philanthropy in a New Gilded Age. New York: Alfred A. Knopf.

Coutts. 2014. "Million Dollar Donors Report 2014."

http://philanthropy.coutts.com/en/reports/2014/russia/findings.html.

Dinello, Natalia. 1998. "Philanthropy in Russia and the United States. Elites and Philanthropy in Russia." International Journal of Politics, Culture and Society 12 (1): $109-133$.

Domrin, Alexander N. 2003. “Ten Years Later: Society, 'Civil Society,' and The Russian State.” The Russian Review 62 (2): 193-211.

Dzutsati, Valery. 2014. "Kremlin Pushes Dagestani Billionaires to Invest in Dagestan." Eurasia Daily Monitor 11, www.jamestown.org/single/?tx_ttnews\%5Btt_news\%5D=42543\&no_cache=1\#.Vu_o jOKLTIU.

Edwards, Michael. 2010. Small Change: Why Business Won't Save the World. San Francisco: Berrett-Koehler Publishers. 
Edwards, Michael. 2008. "Philanthrocapitalism. After the Goldrush." openDemocracy, March 20, www.opendemocracy.net/node/36008/print.

Fitzpatrick, Sheila. 2015. On Stalin's Team: The Years of Living Dangerously in Soviet Politics. Princeton, NJ: Princeton University Press.

Forbes. 2012. "The Forbes 400 Summit: Bill Gates, Warren Buffett and the Greatest Roundtable of All Time," October 8, www.forbes.com/sites/randalllane/2012/09/18/the-forbes-400-summit-bill-gateswarren-buffett-and-the-greatest-roundtable-of-all-time/\#450aaad81c84.

Forbes Russia. 2017. "200 Bogateishchikh Biznesmenov Rossii 2017.” www.forbes.ru/rating/342579-200-bogateyshih-biznesmenov-rossii-2017.

Freeland, Chrystia. 2013. Plutocrats: The Rise of the New Global Super-Rich. London: Penguin.

Gambrell, Jamey. 2004. "Philanthropy in Russia: New Money under Pressure." Carnegie Reporter 3 (1), www.carnegie.org/reporter/09/philanthropy/index.html.

Hamburg, Gary M. 2010. "Russian Intelligentsias." A History of Russian Thought, edited by William Leatherbarrow and Derek Offord. Cambridge: Cambridge University Press: 44-69.

Hosking, Geoffrey. 2014. Trust: A History. Oxford: Oxford University Press. 
Keating, Giles, Michael O’Sullivan, Anthony Shorrocks, James B. Davies, Rodrogo Lluberas, and Antonios Koutsoukis. 2013. Global Wealth Report 2013. Zurich: Credit Suisse AG.

Khodorova, Julia. 2014. Russia Giving: Research on Individual Giving in Russia. Moscow: Charity Aid Foundation Russia.

Kryshtanovskaia, Ol'ga. 2004. Anatomiia Rossiiskoi Elity, Moskva: A. V.

Kurilla, Ivan. 2002. "Civil Activism without NGOs: The Communist Party as a Civil Society Substitute.” Demokratizatsiya: The Journal of Post-Soviet Democratization 10 (3): 392-400.

Leveda-Centre. 2014. "Rossiiane o Biznese i Biznesmenakh.” November 5, www.levada.ru/2014/11/05/rossiyane-o-biznese-i-biznesmenah/.

Livshin, Alexander, and Richard Weitz. 2006. "Civil Society and Philanthropy Under Putin.” International Journal of Not-for-Profit Law 8 (3): 7-12.

Lloyd, Theresa. 2004. Why Rich People Give. London: Association of Charitable Foundations.

Mauss, Marcel. [1898] 2002. The Gift: The Form and Reason for Exchange in Archaic Societies. Forword by Mary Douglas. London: Routledge Classics. 
McGoey, Linsey. 2012. "Philanthrocapitalism and its critics.” Poetics 40: 185-199.

McGoey, Linsey. 2015. No Such Thing as a Free Gift: The Gates Foundation and the Price of Philanthropy. London: Verso.

Ostrower, Francie. 1995. Why the Wealthy Give: The Culture of Elite Philanthropy. Princeton, NJ: Princeton University Press.

Robertson, Graeme B. 2009. "Managing Society: Protest, Civil Society, and Regime in Putin's Russia," Slavic Review 68 (3): 528-547.

Scheidel, Walter. 2017. The Great Leveler. Violence and the History of Inequality from the Stone Age to the Twenty-First Century. Princeton: Princeton University Press.

Schimpfössl, Elisabeth. 2014. "Russia's Social Upper Class: From Ostentation to Culturedness." The British Journal of Sociology 65 (1): 63-81.

Schimpfössl, Elisabeth. 2018. Rich Russians: From Oligarchs to Bourgeoisie. New York: Oxford University Press.

Simon Pirani, 2010. Change in Putin's Russia: Power, Money and People. London: Pluto. 
Simmel, Georg. [1908] 1992. "Exkurs über den Adel.” Soziologie: Untersuchungen über die Formen der Vergesellschaftung. Frankfurt/M.: Suhrkamp.

Skolkovo Center for Management. 2015. Issledovanie Vladel'tsev Kapitalov Rossii. Moscow: Center for Management, Wealth and Philanthropy.

Starinskaia, Galina. 2018. 'Vladel’tsy gruppy 'Summa’ Ziiavudinu Magomedovu grozit do 30 let lisheniia svobody.” Vedomosti, April 1, www.vedomosti.ru/business/articles/2018/04/02/755524-ziyavudinu-magomedovu.

Therborn, Goran. 2013. The Killing Fields of Inequality. Cambridge: Polity Press.

Tikhonova, Natalya E., and Svetlana V. Mareeva. 2016. "Poverty in Contemporary Russian Society: Formation of a New Periphery.” Russian Politics 1 (2): 159-183.

Uhlin, Anders. 2006. Post-Soviet Civil Society: Democratisation in Russia and the Baltic States. London: Routledge.

Weber, Max. 1991. From Max Weber: Essays in Sociology. Translated and edited by Hans Heinrich Gerth and C. Wright Mills. London: Routledge.

\section{Endnotes}


${ }^{1}$ This study served as model for many others. It was replicated in the United Kingdom (albeit following a more practice-oriented concept) by Theresa Lloyd in 2004, with a follow-up she wrote together with Beth Breeze in 2013.

${ }^{2}$ All wealth indicators are taken from Forbes Russia. 